\title{
नेपालमा बैष्णव धर्मको प्रचार
}

\author{
सुशीलकुमार अधिकारी, विद्यावारिधि \\ उपप्राध्यापक \\ संस्कृति विभाग, महेन्द्र मोरङ आदर्श बहुमुखी क्याम्पस, विराटनगर \\ sushil.adhikari23958@gmail.com \\ DOI: https://doi.org/10.3126/dristikon.v11i1.39172

\section{लेखसार}

प्रस्तुत अध्ययन नेपालमा वैष्णव धर्म प्रभावका कारक मुख्य समस्यामा केन्द्रित रहेको छ। गुणात्मक अनुसन्धान विधि र द्वितीयक स्रोतबाट सामग्री सड्कलन गरी विश्लेषणात्मक विधिबाट निष्कर्ष निकालिएको यस अध्ययनमा नेपाली समाजमा वैष्णव धर्मको स्थापना र यसको विस्तारको कारण खोजिएको छ। आर्यवर्तका रूपमा परिचित नेपाल र भारतमा वैदिक कालदेखि प्रचलनमा रही वर्तमानसम्म विस्तारित र अस्तित्वमा रहेको वैष्णव धर्मको स्थापना र विस्तारमा नेपालका शासक र तिनको यस धर्मप्रतिका आस्था र विश्वास नै प्रमुख कारकका रूपमा रहेको निष्कर्ष निकालिएको छ।

शब्दकुज्जी : संस्कृति, साँस्कृतिकता, गायत्री मन्त्र, वैष्णव, धर्म

\section{विषय परिचय}

नेपालका जनताहरू नेपाली सभ्यताको प्रारम्भदेखि नै धर्मभीरू रहेका छन्। नेपाल शब्दले यो देशलाई चिनाउनु अघि नै यहाँका निवासीहरू धर्मप्रधान सोच र व्यवहारमा अभ्यस्त भइसकेकाले हिन्दू धर्मको प्रभाव यहाँ प्रारम्भदेखि नैरहेको छ। हिन्दू धर्मको प्रभावका अतिरिक्त अनेक सम्प्रदायहरूको प्रत्यक्ष प्रभाव पनि यहाँ प्रारम्भदेखि नै रहेको छ। देशको नाम नेपाल भनेर उल्लेख गर्ने पहिलो श्रोत अर्थकपरिशिष्ट हो जुन ईशापूर्व ५००६०० वर्ष पुरानो रहेको छ। यसपछिको ईशापूर्व ३०० वर्षपूर्व कौटिल्यको अर्थशास्त्रमा पनि “नेपाल" शब्दको उल्लेख परेको छ। त्यतिबेलादेखि नै यो देशसंगठित र व्यवस्थित राज्यको स्वरूपमा रहेको छ। यस देशमा संगठित र व्यवस्थित रूपमा गोपालवंशीले शासन गर्नुभन्दा अगाडि नागवंशीको बसोवास रहेको देखिन्छ। यस क्रममा काठमाडौं उपत्यकामा पहिलोपटक दक्षिणतिरबाट बसाई सरेर आउने समुदाय गोपालवंशका थिए। त्यो समूहको नेतृत्व भगवान श्री कृष्णले गरेका थिए भनेर बताइएको छ। यस आधारमा भगवान कृष्णका साथमा उपत्यका प्रवेश गरेको विवरणले उनीहरू वैष्णव मतावलम्बी देखिएका छन्। यसप्रकार त्यसैसमयदेखि नेपालमा वैष्णव धर्मको अस्तित्व कुनै न कुनै प्रकारले रहेको छ।

मानव समुदायले आफ्नो विकासको क्रममा आफूलाई संगठित, व्यवस्थित र चेतनशशील व्यवहारिक प्राणी बनाउन गरेको प्रयत्न र सड्घर्षको फलस्वरूप परिवार र समाजले पालना गर्नुपर्ने त्यस्ता विश्वास र आस्थाको परिकल्पना गय्यो जसले कालान्तरमा "धर्म" नामको सामाजिक व्यवहारको उदय भयो। प्रकृतिप्रदत्त विभिन्न चमत्कारिक परिदृश्य, प्राकृतिक विपत्तिका घटनाहरू, ऋतुपरिवर्तन, चट्याड़, मेघगर्जन जस्ता आफ्नो काबुभन्दा बाहिरको परिस्थितिजन्य प्राकृतिक गतिविधिबाट आत्तिएर, अत्तालिएर वा डराएर मानवले यी सबै घटनाक्रममा अदृश्य शक्तिको हात होला भन्ने कल्पना गरी त्यस्तो शक्तिशाली अदृश्य शक्तिको कल्पना गयो, यस्तै अदृश्य 
निराकार शक्तिलाई पछि, उसले भगवानको नाम दियो र विभिन्न परिस्थितिअनुसार पालनहारी, संहारकारी, विनाशकारी, जन्मदाता आदि रूपमा अनेकौं भगवानहरूको कल्पना गयो। आकाशका, पृथ्वीका र अन्तरिक्षका देवता भनी वर्गीकरण गरेर बहुदेववादको कल्पनाले भगवान र धर्मको मानव समुदायमा पर्न गएको प्रभाव धारण गर्ने अर्थमा बुभदा धर्मलाई त्यस्तो उन्नत र असल सामाजिक ब्यवहारको रूपमा परिभाषित गर्न सकिन्छ। असल सोच, चिन्तन, चेतना, आचरण, विचार, भोजन, वचन, पहिरन, व्यवहार, कर्म, सम्पूर्ण प्राणीप्रति दया र करूणाको भावना आदि धर्ममा सन्निहित गुणको रूपमा व्याख्येय रहेका छन् । यसर्थ धर्म/संस्कृतिको त्यस्ता शाखत र अविभाज्य, अखण्डित अंश हो जसमा कुनै पनि मानव समुदायको सिड्गो संस्कृतिमाथि कहिलेकाहीं धर्मको गहिरो हस्तक्षेप वा प्रभाव हुनसक्दछ। चेतनाको स्तरबृद्धिसंगै संस्कृतिको विराट स्वरूपलाई धर्मले आफूमा समाहित गर्ने दुस्साहस पनि गर्ने गर्दछ। समग्रमा संस्कृतिको विराट आँगनमा धर्म सँधै चन्चल र चलायमान रूपमा विचरण गर्ने गर्दछ। विराट संस्कृतिको सूक्ष्म अंश भए पनि धर्मले मानवजीवनमा अत्यन्त व्यापकता बोकेको छ। सम्पूर्ण मानवजीवनमा धर्मले यति व्यापक र गहिरो असर प्रदान गरेको छ की कहिलेकाहीं धर्मले संस्कृतिको आँगन नाघी बाहिरसम्म आफ्नो प्रभाव विस्तार गर्न खोज्दछ।

जयशड्कर मिश्रद्वारा लिखित “प्राचीन भारतका सामाजिक इतिहास" नामक पुस्तकमा वैष्णव धर्मसम्बन्धी विस्तारपूर्वक चर्चा गरिएको छ। आर्य-हिन्दू संस्कृतिका महत्त्वपूर्ण पक्षहरूको जानकारी दिने यस पुस्तकमा तत्कालीन समाजका सबै पक्षहरूको सविस्तार वर्णन, वैष्णव धर्मको उद्भव र विकास, वासुदेव र भागवत धर्म, वासुदेव र नारायण, वासुदेव र विष्णु, पाँचरात्र मत, वैष्णव धर्मको उत्कर्षकाल आदिका बारेमा विश्लेषणात्मक चर्चा गरिएको छ। समग्रमा यो पुस्तकलाई वैष्णव धर्मका बारेमा जानकारी दिने महत्त्वपूर्ण ग्रन्थको रूपमा लिन सकिन्छ। आर. जी भण्डारगरको “वैष्णववाद, शैववाद र अन्य अल्पस्ख्यक धार्मिक पद्दति" शीर्षकको पुस्तकमा हिन्दू-संस्कृतिभित्रको वैष्णव धर्मका कृष्णयजुर्वेदी सम्प्रदायका बारेमा बृहत् चर्चा गरिएको छ। पाण्डुरड़्ग वामन काँणेद्वारा लिखित “धर्मशास्त्रका इतिहास" भाग-१ मा विष्णु धर्मसूत्रको उल्लेख गर्दे वासुदेव वा विष्णुको पूजा विविधका बारेमा चर्चा गरिएको छ, जसमा वासुदेव वा विष्णुलाई अनादि एवं अनन्त देवताको परिभाषाभित्र राखिएको छ।

वैष्णव धर्मका बारेमा डा. गणेशप्रसाद क्षेत्री र सोमप्रसाद खतिवडाद्वारा लिखित "हिन्दू समाज र धर्म" नामक पुस्तक महत्त्वपूर्ण पुस्तक हो । यस पुस्तकमा विभिन्न धर्मग्रन्थ र साहित्यहरूको उदूरण गरी वैष्णव धर्मका बारेमा विशेष चर्चा गरिएको छ। वैष्णव धर्मको उत्पत्ति, विकास, यसका शाखाहरू र वैष्णव धर्ममा देखिएको विभिन्न अवतारहरूको समेत विस्तृत चर्चा यस पुस्तकमा परेको छ। विभिन्न धर्महरूको उल्लेख गरी लेखिएको पुस्तक "हिन्दू सामाजिक संगठनको प्रारूप" नामक पुस्तक पनि हो । बासु बरालद्वारा लिखित यस पुस्तकमा वैष्णव धर्मका अवतारहरू, गीताका उपदेश र दर्शन, नेपालमा वैष्णव धर्मको परम्परा वेदव्यासको पूजा, वैष्णव तीर्थहरू, वैष्णव मूर्तिहरू आदिको विस्तृत रूपमा चर्चा गरिएको छ। वैष्णव धर्मका बारेमा चर्चा गरिएको पुस्तक डा. प्रेम खत्रीको "नेपालको सामाजिक इतिहास र धार्मिक मतहरू" शीर्षकको पुस्तक पनि हो । यस पुस्तकमा विभिन्न उपशीर्षकअन्तर्गत वैष्णव धर्मका बारेमा चर्चा गरिएको छ। वैष्णव धर्मको प्रारम्भिक इतिहास र विकास, वैष्णव धर्ममा अवतारवाद र विभिन्न अवतारहरू, भागवत गीताको मुख्य उपदेश, पाँचरात्र र वैष्णव धर्मका विषयमा यस पुस्तकमा चर्चा गरिएको छ। खत्रीकै "नेपालका धार्मिक मत र सामाजिक संरचना" शीर्षकको पुस्तकमा वैष्णव धर्मको बारेमा चर्चा गरिएको छ। पेशल दाहाल र सोमप्रसाद खतिवडाद्वारा लिखित "नेपाली समाज र संस्कृतिको परिचय" नामक पुस्तकमा वैष्णव धर्ममा अवतारवाद, नेपालमा वैष्णव धर्म, आदि उपशीर्षकमा वैष्णव धर्मका 
बारेमा चर्चा गरिएको छ। पेशल दाहालको “नेपालको इतिहास र संस्कृति" नामक पुस्तकमा वैष्णव धर्मको परिचय, प्राचीन नेपालमा वैष्णव धर्म र मध्यकालीन नेपालमा वैष्णव धर्म उपशीर्षकमा वैष्णव धर्मका बारेमा चर्चा गरिएको छ। नेपाली र हिन्दी भाषामा लेखिएका प्रस्तुत सन्दर्भग्रन्थमा उल्लेख भएका पूर्वकार्यले वैष्णव धर्मका बारेमा चर्चा गरे तिनले अध्ययन नगरेको नेपालमा वैष्णव धर्मको प्रभाव र कारकलाई अध्ययनको मुख्य समाधेय प्रश्नका रूपमा लिई अध्ययनलाई पूर्णता दिइएको छ।

\section{समस्याकथन}

वैष्णव धर्म नेपाली संस्कृतिभित्रको एक महत्तवपूर्ण धार्मिक पक्षका रूपमा रहेको छ। नेपालमा वैष्णव धर्मप्रभावका कारक विषयक मूल समस्या रहेको यस अध्ययनको पूर्णताका लागि निम्नानुसार शोध्यप्रश्न रहेका छन् :

१. वैष्णव धर्मको उत्पत्ति कसरी भएको छ ?

२. नेपालभित्र वैष्णव धर्मको प्रभावका कारक कसरी विस्तार भएको छ ?

\section{उद्देश्य, महत्त्व र सीमा}

उपर्युक्त शोध र शोध्यप्रश्नको प्राजिक समाधान खोज्नु नै यस अध्ययनको उद्देश्य रहेको छ। यस अध्ययनमा नेपालमा वैष्णव धर्मको उत्पत्ति तथा वैष्णव धर्म प्रचार हुनुका कारण खोर्जिको छ। नेपालमा वैष्णव धर्मको ऐतिहासिक विकासले प्रभावित तुल्याएको सन्दर्भसम्बद्ध गरिएको यस अध्ययनले नेपालमा वैष्णवधर्मको विकास, यसको प्रभावका कारक र प्रचारका विषयमा जानकारी राख्न चाहने पाठकका लागि उपयुक्त सामग्री रहेको छ।

\section{शोधविधि तथा सामग्री}

प्रस्तुत अध्ययनका लागि द्वितीयक स्रोतबाट सामग्री सङ्कलन गरिएको छ। सामग्रीको विश्लेषणका लागि गुणात्मक अनुसन्धान विधि तथा संस्कृतिको अध्ययनअन्तर्गत परम्परागत संस्कृतिभित्रका संस्कार विषयक संस्कृतिका आधारभूत पक्षका आधारमा नेपाली मूल आर्यसंस्कृति कलेवरभित्र वैष्णब धर्मको प्रचलन, विकास, विस्तार र यसका कारकको र निक्यौल गर्न आगमनात्मक विधिबाट उक्त संस्कारको सान्दर्भिता र औचित्यको खोजी गरिएको छ। सामग्री सड्कलनपश्चात् प्राप्त सामग्रीलाई विश्लेषणात्मक विधिको प्रयोग गरी निष्कर्ष निकालिएको छ।

संस्कृति संस्कृत भाषाबाट आएको तत्सम शब्द हो। परम्परागत मूल्य र मान्यताले स्थापित गरेका समसामयिक मानवीय आचरण र व्यवहारसँग कसरी जोडिएर आई मानवीय जीवनपद्धतिलाई परिष्कृत र परिमार्जित गरी अनुशासित जीवन पद्धतितर्फ डोहोन्याउँछ् भन्ने विषयको प्रतिनिधित्व संस्कृतिले गरेको छ। संस्कृति समसामयिक अवस्थामा व्यक्ति र समुदायको पहिचानको आधारका रूपमा पनि व्यवहृत र परिभाषित रहेको छ। मानव सभ्यतासँग जोडिएर आउने भौतिक, अभौतिक पक्षको संश्लेषित पक्ष र त्यसले निर्देशित गर्ने अनुशासित र व्यवस्थित जीवनपद्धतिलाई संस्कृतिअन्तर्गत राखिन्छ जसले बृहत्तर मानव समुदायको आस्था र पहिचानलाई आफ्नो दायरामा समेटेको हुन्छ (अधिकारी, २०७४ : १०)। संस्कृति वैयक्तिक वस्तु नभई भावनात्मक रूपमा जोडिएका समुदायका सदस्य र तिनले गर्ने सामाजिक व्यवहारबाट निसिद्ध वस्तुका रूपमा समाजले ग्रहण गरेको विधि वा पद्धतिको नियमित व्यवस्थाका रूपमा समाजमा अवशिष्ट रहेको हुन्छ (रेग्मी, २०५० : १३)। मानव सभ्यताको विकासको शिलशिलासँगै समाजलाई व्यवस्थित गर्न र सामाजिक गतिविधिको व्यवस्थापनका लागि सचेत र असचेत रूपमा निर्मित सामाजिक व्यवहार र ती व्यवहारबाट निर्देशित रही जीवनपद्धतिको सन्चालन गर्ने एकभाषी समुदायको सामाजिक अवस्थालाई संस्कृति मानिन्छ (भाटिया, फ्लावरडयु र रोडनी २००६ : yू)। संस्कृति 
समुदायले असचेत रूपमा अवलम्बन गरी त्यसैका सापेक्षमा जीवन सन्चालन गर्ने पद्धतिका रूपमा समाजमा स्थापित रहेको हुन्छ जुन कतिपय अवस्थामा भाषा र कतिपय अवस्थामा सामाजिक व्यवहारबाट निशृत रहेको हुन्छ (भाटिया २००६ : २९)। समाज विकासको सुदीर्घ परम्परामा मान्छेले देखेको, भोगेको र अनुभव गरेको जीवनपद्धति र मान्छेलाई निश्चित अनुशासन र अपनत्वको विकास गर्न अभिप्ररित गर्ने प्रमुख माध्यमका रूपमा संस्कृतिको निर्माण गरेको हो भने संस्कृतिको एकांशका रूपमा धर्मको स्थान सुरक्षित रहेको छ। मूलतः संस्कृतिभित्र राष्ट्र, राष्ट्रियता, धर्म, साहित्य, सड्रीत, कला, आचार/व्यवहार, बौद्धिकता जस्ता संज्ञान र तिनको उत्तराधिकारको हस्तान्तरण जस्ता भावात्मक विषय रहेकाछन्। समाजमा रहेका प्रथाबीच एकत्व सिर्जना गरी समाजको गतिशील र विकसित पद्धतिलाई निरन्तरता दिन यसले अहम् भूमिका खेलेको हुन्छ।

कुन पनि मानव समुदायले पालना गर्दे आइरहेको कुनै पनि संस्कार उसको संस्कृतिभित्रको एउटा अंशको रूपमा रहेको हुन्छ ।अर्थात मानव समुदायले आप्नो संस्कृतिभित्र त्यस्ता धेरै संस्कारहरू बोकेर हिडेको हुन्छ, जसले त्यो मानव समुदायको सम्पूर्ण संस्कृतिको निर्माण भएका छन्। विज्ञानवादी मतले पृथ्वीमा मानव जातिको उत्पत्ति क्रमिक रूपमा विकास हुँदै आजको अवस्थासम्म आइपुगेको निष्कर्ष दिएको छ। आफ्नो विकासको लामो इतिहासमा आस्था, विश्वास, संदेदना र सोच मिल्ने समुदायको साका विश्वासका रूपमा स्थापित भएको संस्कृतिभित्र समावेश हुने विभिन्न प्रथा, प्रचलन, धर्म र तिनमा अवशिष्ट समुदायको प्राचीनता पनि नेपाली समा र यसको संरचनासंगै विकसित भएका छन् । नेपालका आर्य समुदायले उपनयन संस्कारका ऋममा ग्रहण गर्ने मन्त्र/दीक्षाको शुभारम्भका रूपमा प्राप्त वस्तु वैष्णव गायत्रीका रूपमा प्राप्त गर्ने साँस्कृतिक मान्यताले पनि नेपाली समाजमा वैष्णव धर्म र यसको प्राचीनतालाई पुष्टि गर्दछ। नेपाली समाजको साँस्कृतिक प्राचीनतासँग जोडिई जीवनपद्दतिको विशेष पाटो भए पनि यो धर्मको उत्पत्ति, प्राचीनता र यसको महत्त्वका बारेमा स्वतन्त्र लेखको अभावपूर्तिका लागि यो आलेख तयार पारिएको हो। कुनै पनि धर्म, कुनै पनि समाजले पालना गर्दे आइरहेको संस्कृतिभित्रको महत्वपूर्ण अंगको रूपमा रहेको हुन्छ, सोही अड्गको अर्थात वैष्णव धर्म र नेपाली संस्कृतिबीचको अन्तर्सम्बन्ध केलाउने प्रयास यस लेखमा भएको छ।

\section{परिणाम तथा छलफल}

मानवजातिले पृथ्वीमा आफ्नो अस्तित्वबोध गरेदेखि नै उसले उन्नत र चेतनशील प्राणी बनाउन आफ्नो बुद्धि र क्षमताको प्रयोग गर्दै आफूलाई व्यवस्थित क्रममा विकास गरेको संस्कृतिको अंशका रूपमा धर्मको स्थापना भएको हो। नवपाषाण काल (ईसापूर्व इ०००-४००००)मै खेतीपाती, पशुपालन र आफूलाई प्रयोगमा आउने दैनिक उपभोग्य वस्तुको आविष्कारसंगै समाज व्यवस्था र समुदायमा अनुशासन स्थापना गर्ने उद्देश्यले निर्माण गरिएका आचार-विचार र प्रथा नै संस्कृतिका रूपमा विकास भएका हुन् । मान्छेमा निहित कल्पनाशक्ति तथा आप्नो वर्चश्व समाजमा स्थापित भइरहोस् भन्ने भावनाबाट अनुप्रणित भई परमतत्त्वको कल्पना र त्उसको मूर्तीकरण गर्ने सन्दर्भमा धर्मले मानव मानसिकतामा स्थान बनाउन सफल भएको हो। यस अध्ययनमा परम्परित संस्कृतिभित्र वैष्णव धर्मको उत्पत्ति, विकास र नेपालमा यसको अस्तित्व स्थापित हुनुका कारणलाई निम्नानुसार चर्चा गरिएको छ :

\section{पूर्वाध्यायनको समीक्षा}

\section{नेपालमा वैष्णव धर्मको उत्पत्ति र विकास}


वैष्णव धर्मको प्रारम्भिक रूप भागवत धर्मअन्तर्गत भगवान बासुदेव अर्थात कृष्णको आराधना वा पूजामा लक्ष्यित देखिएको छ। ईशापूर्व छैठौं शताब्दीमै स्थापित सकेको थियो (मिश्र : इ.स. १९७४ : ६९४) बासुदेव नाम कृष्णको प्रारम्भिक नाम हो, जुन पाणिनीको समय (ई.पू. ६००-३००)मा प्रचलित थियो । यस आधारबाट वैष्णव धर्म ईशापूर्व छैठौं शताब्दीदेखि नै प्रचलनमा रहेको बुभ्न सकिन्छ। यसैगरी पुरातात्त्वक प्रमाणका रूपमा बासुदेव उपासनाको अभिलेखात्मक सामाग्रीहरू ई.पू. चौथो शताब्दीदेखि प्राप्त हुन थालेका देखिएको छ। भारतका राजपुताना इलाकाको घोसुण्डी भन्ने स्थानमा पाइएको एउटा अभिलेखमा बासुदेव र सङ्कर्षणको उपासना मण्डप र त्यसको चारैतिर बनाइने भित्ताको बारेमा चर्चा परेको छ। यो अभिलेखको अक्षरको स्वरूपको आधारमा विद्वानहरूले यसलाई ईसापूर्व दोश्रो शताब्दीको मानेका छन् (भण्डारकर, ३)। यसै सभ्यताकाको यवनदूत होलियोदोरले बासुदेवको सम्मानमा गरूडध्वज राखेको कुराको उल्लेख वेशनगरको अभिलेखमा पर्नुले ई.स. दोश्रो शताब्दीमा बासुदेव देवाधिदेव भइसकेका र उनका भक्तहरू भागवतका रूपमा समाजमा स्थापित भइसकेको देखिन्छ। त्यसैगरी भागवत धर्म त्यसताका उत्तरपश्चिम भारतमा पूर्णरूपमा स्थापित भइसकेको र ग्रीक ( यवन)हरूले समेत यस धर्मलाई सम्मान गरेको (अपनाएको) स्पष्ट हुन्छ (क्षेत्री, खतिवडा, २०६४ : ३०)। यस आधारमा ईसापूर्वको महाभारतकालीन वा बुद्धकालीन समयमा वैष्णव धर्मको गहिरो उपस्थिति देखिएको छ। महाभारतमा बासुदेव नाम अनेकौंपटक आएको छ। महाभारत भीष्मपर्वमा भीष्मद्वारा व्यक्त भनाइअनुसार यो नित्य, मड्गलमय, अद्भूत अनुरागी देवतालाई बासुदेवको रूपमा बुभ्मुपर्दछ, जसको भक्तिसहित ब्राह्मण, क्षेत्रीय, वैश्य, शुद्र सबैले पूजा गर्दछन् (मिश्र, ६९५)। महाभारत लेखनको समय यकिन हुननसके पनि यो प्राचीन ग्रन्थ हो । जसमा बासुदेवको अनेकौंपटक उल्लेख आउनुका साथै महाभारतको सन्दर्भहरूको समग्र विश्लेषण गर्दा भक्ति, उपासना वा वैष्णव धर्मको उदय महाभारत कालभन्दा निकै अगाडि भइसकेको तर यसलाई निश्चित स्वरूप दिने काम भने बासुदेव (कृष्ण)ले अर्जुनलाई गीताको उपदेश दिने कार्यद्वारा पूरा गरेको स्पष्ट हुन्छ। साहित्यिक श्रोतहरूको यसप्रकारको उल्लेख र वर्णनको आधारमा पाइएको सड्केत ईसापूर्वकै समयदेखि वैष्णव बासुदेव वा भागवतका नामले सम्बोधित वैष्णव धर्म सम्प्रदायको उल्लेख ईसाको प्रथम शताब्दीदेखि प्राप्त हुन्छ। विष्णु धर्मसूत्रमा (१००-३०० ईसापछि) बासुदेव वा विष्णुपूजाको सबैभन्दा प्रारम्भिक स्वरूप वा उल्लेख पाइन्छ, जसमा राम्ररी नुहाइ-धुवाई गरी आचमन गरेर यजस्थलमा मूर्ति राखी वा मूर्ति समक्ष अनादि एवं अनन्त बासुदेवको पूजा गर्नुपर्ने उल्लेख परेको छ (काँणे, ३९६)। ईशाको पहिलो शताब्दीमा यस सम्प्रदायका उपाष्य देवताहरूको प्रतिमा र आकृति पाइन्छ। प्रतिमा वा आकृतिमा माथितिरको बाँया हातमा चक्र लिएको चारहाते पहिलो प्रतिमा कुषाण राजा हविष्कको सिक्कामा देखापर्दछ (क्षेत्री, खतिवडा, ३१) यसप्रकार प्राचीन कालदेखि नै प्रचलित वैष्णव धर्मका बेग्लाबेग्लै विकासका युग र दिनहरूमा बेग्लाबेग्लै धर्मगुरू र विद्वानहरूले महत्त्वपूर्ण भूमिका खेल्दे आए। यस धर्मअन्तर्गतका विभिन्न साहित्यिक ग्रन्थहरू भागवत पुराण, विष्णु पुराण, गरूड पुराण आदिको रचना पनि विभिन्न समयमा हुनपुग्यो। यसका साथै यस धर्मसम्प्रदायमा विभिन्न शाखा-उपशाखाहरूको रूपमा विकासक्रम अगाडि बढ़दै आएको छ।

वैदिककालदेखि नै अस्तित्वमा रहेको वैष्णव वा बासुदेव धर्म सम्प्रदायको महत्त्वपूर्ण शाखा वा मत "पाँचरात्र" मत हो । यो पाँचरात्र मतको विकास वा प्रादूर्भाव ई.पू. तेश्रो शताब्दीमै भइसकेको हो (मिश्र, ७०१)। यो सम्प्रदाय वा मतअन्तर्गत बासुदेव र उनको अनेक स्वरूपलाई पूजा आराधना गर्दछन्। यस मतअनुसार सकल ब्रम्हाण्डको बीज “पौरूषी रात्री" (प्रलय)को रूपमा भगवान बासुदेवमा सन्निहित वा समाहित हुन्छ। पाँचरात्र समुदायमा बासुदेव, सड्कर्षण, प्रघुम्न, अनिरूद्र र शाम्ब आदिको उपासना गर्ने चलन रहेको पाइन्छ। यस 
सम्प्रदायमा पूजाका $y$ विधिहरू अपनाइने हुनाले यसलाई “पाँचरात्र" सम्प्रदाय भनिएको हो । पाँचरात्र सम्प्रदायबाहेक ई.पू. तेश्रो शताब्दीदेखि नै एकान्तिक र बैरवानस सम्प्रदाय पनि महत्त्वपूर्ण सम्प्रदायको रूपमा प्रचलन र अस्तित्वमा रहँदे वैष्णव धर्मले आफ्नो मार्ग पहिल्याएको छ।

वैष्णव धर्मको विकासको विवरण दिँदा र यसका विकासका चरणहरूको बारेमा चर्चा गर्नुपर्दा यस धर्मको दार्शनिक पक्षलाई आधार मानेर जनसमक्ष ल्याउने आचार्यहरूको योगदानलाई बिर्सन सकिंदैन। अहिंसक र भक्तिमार्गको व्याख्या- विश्लेषण गरी भक्तिमार्गद्वारा भगवान प्राप्ति गर्ने माध्यम बताइएको यस मतका विभिन्न शाखा प्रशाखाहरूको पनि विकास भएको छ। यस ऋममा यस मतका अनुयायी आचार्यहरूले आआफ्ना प्रकारले यस मतको प्रचार-प्रसार गरे, जसमा प्रमुख व्यक्ति रामानुज थिए। यिनले प्रतिपादन गरेको मतलाई "विशिष्टौत्व" भनिएको छ। जुन आचार्य शङ्करद्वारा प्रतिपादित मायावादलाई (अद्वैत्ववाद) खण्डन गरी विकसित गरिएको छ। जुन सम्प्रदाय हाल नेपाल र भारतमा अस्तित्व रहेको “श्री वैष्णव" सम्प्रदायको रूपमा चर्चित हुदै प्रचलनमा रहेको छ। यस सम्प्रदाय वा मतको प्रमुख ग्रन्थहरूमा वेदान्तसार, वेदार्थसड्ग्रह, वेदान्तदीप , ब्रह्मसूत्र-भगवद्गीता भाष्य मुख्य रहेका छन् भने यिनले प्रतिपादन गरेको वेदान्त सिद्धान्तले जीव, जगत् र परमात्माका विषयमा सविस्तार वर्णन गरेको छ। रामानुज (ई. स. १०१६) पश्चात ११औं शताब्दीमा आचार्य शड्करद्वारा प्रतिपादित अद्वैतवाद र रामानुजद्वारा प्रतिपादित विशिष्टाद्वैत्ववादको मूलस्वरूपलाई अस्वीकार गर्दे आचार्य मध्वाचार्य (११औं शताब्दी)ले ब्रह्मसम्प्रदायको रूपमा "द्वैत्व" दर्शनको प्रचार गरे (मिश्र, ७१)। द्वैत्व मतमा ईश्वर पनि सत्य हो र जगत् पनि सत्य हो भन्ने विश्वास गरिन्छ। वैष्णव सम्प्रादायको अर्को मतलाई भद्र सम्प्रदाय मानिएको छ। जसका आचार्य विष्णुस्वामी तथा प्रमुख अनुयायी आचार्य बल्लभ मानिन्छन्। यिनीहरूले विकास गरेको मतलाई "शुद्धाद्वैत" भनिएको छ। आचार्य बल्लभ (ई. स. १४६९) वा वल्लभाचार्यले प्रतिपादित गरेको यस मर्गको नाम पुष्टिमार्ग पनि रहेको छ। यिनले शड्कराचार्यको वेदान्त दर्शनभन्दा आफ्नो दर्शन अलग छ भन्ने देखाएर अद्वैत्वको अगाडि शुद्ध थपेर "शुद्धाद्वैत्व" बनाएको छ। यस मतमा ब्रह्मालाई परमब्रह्म, अन्तर्यामी ब्रह्म र अदारब्रह्म गरी तीन प्रकारमा विभाजन गरेको छ। वैष्णव धर्मको अर्के प्रमुख मतका रूपमा आचार्य निम्बार्कद्वारा प्रतिपादित “द्वैताद्वैत" दर्शन रहेको छ। १२औं शताब्दीका आचार्य निम्बार्कद्वारा प्रतिपादित यस मतका अनुयायीहरू हाल नेपाल र भारतको उत्तरी भू-भागमा प्रशस्त भेटिन्छून्, जसलाई "निम्बार्की" वैष्णव भन्ने चलन रहेको छ। वास्तवमा हिन्दु धर्मको प्रमुख ग्रन्थ वेदको सड्ख्या चार रहे जति वैष्णव सम्प्रादयमा पनि चार प्रमुख आचार्यहरूले चार प्रमुख सम्प्रादायको वा मतको विश्वास गरी वैष्णव धर्मलाई हिन्दु धर्म-संस्कृतिको महत्त्वपूर्ण धर्म-सम्प्रदायको रूपमा स्थापित गराउन भूमिका निभाएको छ।

\section{नेपालमा वैष्णव धर्मको प्रचार}

नेपाल वैष्णव धर्मका लागि उर्वर भूमिको रूपमा रहेको छ। यहाँ परापूर्वकालदेखि नै वैष्णव धर्म फल्दै-फूल्दै आएका असड्ख्य प्रमाणहरू प्राप्त भएका छन्। साधारण जनता मात्र नभएर शासक वर्गमा समेत यो धर्मको विशेष प्रभाव रहेको छ। यसर्थ नेपालमा वैष्णव धर्मको इतिहास धैरै पुरानो रहेको मानिएको छ। जुन समयदेखि नेपालको प्राभाषिक इतिहास बारे प्रमाणहरू उपलब्ध हुन्छन् त्यसै समयदेखि भगवान विष्णु नेपालीहरूका एक प्रमुख र पूज्य देवता मानिदै आएका छन् तर उनको इतिहास (भगवान विष्णुको पूजा आराधना) त्योभन्दा धेरै पुरानो रहेको छ। हाम्रो देशको इतिहास जान्ने श्रोतहरूमध्ये विभिन्न समयमा लेखिएका वंशावली पनि एक हो। प्रचलित भाषा वंशावलीअनुसार हालको काठमाडौं उपत्यकामा एक समय तलाउ रहेको थियो त्यसबेला भगवान श्री कृष्ण यहाँ आई तरबारले चोभारको डाँडो काटी पानी बग्ने बाटो बनाएपछि पानी बाहिर तलाउ सुकेपछि, आफूसंगै आएका 
गोपाल जातिका मानिसहरूको बस्ती बसाए भन्ने वंशावलीमा उल्लेख पाइन्छ (नेपाल, ३६) भाषा वंशावलीको स्रोतअनुसार काठमाडौं उपत्यकाको प्रथम बस्ती बसाउने नै वैष्णव धर्मका उपास्य देवता श्री कृष्ण थिए। वैदिक सभ्यताकाल ई. पु. १४०० देखि ई. पु. प००० वर्षसम्म मानिएको छ। यस आधारमा हेर्दा नेपालको गोपालवंशको काललाई पनि वैदिक कालको समकालीन मान्निन्छ। वैदिककालमा अर्थात् ऋग्वेदमा (ई. पु. १५००) विष्णुलाई आकाशमा डुली हिंड्ने सूर्यको प्रतिरूप मानिएको छ। यिनको प्रतिष्ठा ऋग्वेद कालभन्दा पछिल्लो कालमा बढोत्तरी भएको छ। यस अर्थमा नेपालको गोपाल वा महिषपाल कालमा पनि विष्णुलाई यस अवस्था र स्वरूपमा कल्पना गर्दे त्यसको कुनै विशिष्ट मत वा सम्प्रदायको रूपमा विकास नगर्न प्ररम्भिक देव स्वरूप मात्र निर्माण भएको थियो । नेपालको गोपालवंशले पनि प्रारम्भिक देवको रूपमा विष्णुको अस्तित्वलाई स्वीकार गरेको छ। विष्णुलाई वा वैष्णव मतलाई वास्तवमा भारतवर्षमा वा समग्र आर्यावर्तमा प्रचीन देवाताको रूपमा स्वीकार गर्दे मध्यकालमा यसलाई छुछ्टै सम्प्रदायको रूपमा विकास गर्ने सोच वा उत्तरवैदिकालीन उपनिषद्हरूले व्याख्या गरेको दार्शनिक तत्त्वको व्याख्या विश्लेषणले अनुप्रणित गर्दे यसका विभिन्न मतहरूको विकास गरिएको छ। तसर्थ नेपालको सन्दर्भमा पनि गोपालवंश र महिषपाल वंश जुन वैदिककालको समकालीन देखिएको छ यस कालमा वैष्णव धर्मको प्ररम्भिक स्वरूपको मात्र अस्तित्व नेपालमा देखापर्दछ।

वर्तमान समयमा तराईमा अवस्थित जनकपुर क्षेत्र उत्तरवैदिक कालमा विदेह राजा जनकको राज्य मिथिलाको राजधानीको रूपमा रहेको थियो उत्तरवैदिककालीन विभिन्न श्रोतहरूमा विदेहको नाम उल्लेख भएको छ । त्यसताका मिथिला नगरी (राज्य) वैष्णव धर्मको ज्ञान र दर्शनको केन्द्रको रूपमा रहेको थियो भने काठमाडौं उपत्यकामा ईसाको प्रारम्भदेखि लिच्छवी वंशका शासकहरूले शासनसत्ताको शुरूवात गरेका थिए। उनीहरूको मूलधर्म वैष्णव नै रहेको छ। त्यो युगमा निर्मित विष्णुका मूर्तिहरूले उक्त कुराको पुष्ट्याइँ गर्दछन्। काठमाडौं उपत्यकामा चार नारायणको स्थापना यसै युगमा भएको मानिन्छ। वैष्णव धर्मावलम्बीहरूको महत्त्वपूर्ण तीर्थस्थलको रूपमा रहेका यी चार नारायणहरू मध्ये चाँगुनारायण र इचड्गुनारायणमा आजसम्म पनि बर्षेनी ठूलो मेला लागदछ। लिच्छवी वंशका ऐतिहासिक र प्रमाणिक राजा मानदेव (४ २१-५६२)को पालादेखि भने नेपालमा वैष्णव धर्मको विकासको इतिहास निकै स्पष्ट हुनथालेको हो। लिच्छवी राजा मानदेवले पहिलेदेखि नै निर्मित चाँगुनारायणको मन्दिरमा शिलालेख राखेका थिए जुन चाँगुनारायणको अभिलेखको रूपमा प्रसिद्ध छ। यस अभिलेखको प्राप्तिले नेपालको प्रामाणिक इतिहासको प्रारम्भ गरेकाले समग्र नेपालको इतिहासमा मानदेवको यो अभिलेख अत्यन्त महत्त्वपूर्ण र ऐतिहासिक सिद्ध भएको छ। यो अभिलेखको अग्रभागको प्रारम्भमा नै उनले चाँगुनारायणको स्तुति लेखाएका छन् । जसबाट प्रष्ट रूपमा उनी वैष्णव धर्माबलम्बी रहेको बुकिएको छ। बज्राचार्य, १०)। मानदेवका अन्य अभिलेख्य सामाग्री र श्रोतहरूले पनि उनी वैष्णव धर्मप्रति आस्थावान रहेको र त्यसबेला वैष्णव धर्म राजकीय धर्मकै रूपमा रहेको थियो। राजा मानदेवले त्यतिबेला पशुपतिनेर तिलगड्गा भन्ने स्थानमा र लाजिम्पाटमा अभिलेखसहित त्रिविक्रम विष्णुका मूर्तिहरू स्थापना गराए (पृ., ३४/३४) यी दुवै मूर्तिहरू विष्णुको अवतार वामनसँग सम्बन्धित हुन । यसैगरी मानदेवको “मानाङ्क" नामक मुद्राको पृष्ठ भागमा अड्कित लक्ष्मीको चित्र र कमलका फूलहरूले राजाको वैष्णव धर्मप्रतिको आशक्ति प्रकट हुनपुगेको छ (बराल, ४३९)। लिच्छवी राजा मानदेवपछिका शासकहरूमा पनि वैष्णव धर्मप्रतिको अनुराग र आस्थामा कुनै कमी आएको छैन । उनीपछिका राजा बसन्तदेवका $२$ वटा अभिलेखहरूको शीर्षभागमा चक्र र त्यसको दुईतिर शड्ख्य अड्कित गरिएको छ। यसका साथै बसन्तदेवका अन्य २ वटा अभिलेखमा उनलाई “परमदेवता" मानिएको छ। यस आधारले बसन्तदेवलाई वैष्णव धर्मप्रति पूर्णतः आस्थावान शासक मान्न सकिन्छ भने वैष्णव उपाधि लिने प्रथम शासक 
मानिन्छ। यसैगरी बसन्तदेवका छोरा वामदेव पनि वैष्णव थिए। उनको एकमात्र अभिलेखमा उनले वामन स्वामीलाई जग्गा दान दिएको उल्लेख परेको छ (बज्राचार्य, ९१/१२४/१२६)। नेपालको लिच्छवीकालीन इतिहासमा द्वैतशासकको रूपमा देखिएका आमिर गुप्तहरू पनि वैष्णव धर्मावलम्बी नै रहेका छन् । ऐतिहासिक राजा मानदेवपछिका शासक बसन्तदेवका पालादेखि शासनसत्तामा सक्रिय देखिंदै आएका यी गुप्तहरूमा भौमगुप्त, रविगुप्त, जिष्णुगुप्त प्रमुख थिए। यिनीहरूको समयसम्म पनि वैष्णव धर्म राजधर्मकै रूपमा रहेको छ। यस समयका शिलालेखहरूको शिरोभागमा शड्ख, चक्र आदिको चित्र अड्कित भएका छन्। शिलालेखहरूमै विष्णु, वेदव्यास, बासुदेवका नाममा सुन्दर पड्कित् पनि उत्कीर्ण गरिएको छ। यससमयको बासुदेव ब्राह्मण गोष्ठी नाम लेखेको एक शिलालेख पाइएको छ (खत्री, २ू१)। समग्र लिच्छवीकालको कलामा वैष्णव धर्मको छाप सर्वाधिक महत्त्वपूर्ण छ। यसबेलाबनेका त्रिविक्रम विष्णु, विष्णु विश्वरूप, धुम्बाराही, कालीयदमन, जलाशयन विष्णु, गरूडनारायण, गरूडहरू, शड्कर, लक्ष्मीनारायण आदिका उत्कृष्ट कलाकृतिहरूले त्यसबेला वैष्णव धर्मको लोकप्रियता दर्शाउँछ।

लिच्छवीकालमा राजा मानदेवद्वारा निर्मित त्रिविक्रम मूर्ति ऋग्वेदमै वर्णित लामालामा पाइला चालेर हिंड्न सक्ने र आफ्नो तीन पाउले तीन लोकलाई ढाक्न सक्ने सामर्थ्य भएका विष्णुको बयानसँग मिल्दोजुल्दो रहेको देखिएको छा रिग्वेदमा बिष्णुलाई पर्वतीय सिंहसँग तुलना गरिएको छ भने यिनलाई सूर्यसँग जोडेर चर्चा गरिएको छ। लिच्छवीकालमा अस्तित्वमा रहेको वैष्णव धर्मले विष्णुको प्ररम्भिक स्वरूप, शक्ति र सामर्थ्यलाई अड़ीकार गरेको छ। यसकालमा मुख्य रूपमा विष्णु वा वैष्णव धर्मको अस्तित्व र प्रभाव दर्शाउन विष्णु मुर्ति बनाउने र उनका हतियार र अरू साङ्केतिक चिन्हहरू प्रदर्शित गर्ने गरिएको छ। लिच्छवीकालीन शासनव्यवस्था र समाज वैदिक धर्मअनुसार नै गठित र संगठित हुनुका साथै शासनसत्ताको आधार धर्म नै भएकाले वैदिक साहित्य नै यसकालको संस्कृतिको अड्ग र पथप्रदर्शक भएका कारण लिच्छवीकालीन वैष्णव धर्मको प्ररम्भिक स्वरूपमा त्यति जटिलता देखिएको छैन। नेपालको लिच्छवीकाल भनेर ईसाको पहिलो शतब्दीदेखि नवौं-दशौं शताब्दीसम्मको समयलाई बुक्किने भएको हुँदा वैष्णव धर्मको विकासक्रम पनि सोही समयमा भएको विकासकै पदचिह्नमा अगाडि बढेको देखिन्छ।

लिच्छवीकलीन प्रसिद्ध राजा मानदेव (वि.स. प२१-प६२) आफु वैष्णव धर्मावलम्बी भएको बताएको कारणले त्यस समयमा वैष्णव धर्म राजकीय धर्म वा राष्ट्रिय धर्मकै रूपमा रहेको अनुमान गरिएको छ। त्यस समयमा भारतमा पनि शासकहरूले वैष्णव धर्मका विष्णुलगायतका ठूलाठूला मूर्तिहरू र मन्दिरहरू बनाई आफ्नो आस्था प्रकट गरेका कारणले यो धर्म जनस्तरसम्म पनि लोकप्रिय रहेको छ। लिच्छवी कालभरि वैष्णव धर्मको प्रमाण दिने लगभग ३३ अभिलेख पाइएका आधारमा ईसाको नवौँ शताब्दीसम्म नेपालमा वैष्णव धर्म प्रचलित धर्मको रूपमा स्थापित भइसकेको र यसका विभिन्न सम्प्रदाय वा शाखाहरूको विकास भएको हो। यसकालमा विष्णुका मूर्तिहरूका अतिरिक्त यिनका अवतारसँग सम्बन्धित वामन, वेदव्यास, नरसिंह, बलराम, जलाशयन विष्णु, गरूडनारायण, बराह अवतार, राम, पर्शुराम आदिका मूर्ति र मन्दिरहरू स्थापना भएको छ। यसकालको प्रसिद्ध जलाशयन विष्णुको मूर्ति बुढानीलकण्ठ रहेको छ, धुमबाराहीमा अवस्थित बराहको मूर्ति उल्लेखनीय रहेको छ। यसैगरी लिच्छवीकालीन वैष्णव धर्मको प्रसिद्ध र प्रामाणिक मूर्ति र मन्दिर चाँगुनारायण मन्दिर रहेको छ। यसप्रकार लिच्छवीकालको लगभग ९००-१००० वर्षको समयमा विष्णुको प्रचीन स्वरूप र उनको अवतारसँग सम्बन्धित मूर्ति र मन्दिरहरूको उपस्थितिले तत्कालीन समयको वैष्णव धर्मसम्बन्धी जानकारी पाइएको छ। 
नेपालमा मध्यकालमा पनि वैष्णव धर्म लोकप्रिय रहेको छ। यस समयको पहिलो अभिलेख वि.स. १११३ को चाँगुनारायण मन्दिरमा रहेको चाँगु अभिलेख हो। यसका साथै मध्यकालीन अभिलेखहरूले वैष्णव धर्मको बारेमा जानकारी दिने गर्दछन्। यसकालका प्रसिद्ध राजा जयस्थिति मल्लले वैष्णव धर्मको विकासमा महत्तवपूर्ण योगदान पुच्याएका थिए। यसका अतिरिक्त त्यसकालका कतिपय शासकहरूले वैष्णव उपाधि "परमद्वैत" धारण गरेको देखिन्छ। यसकालका शासक अरिमल्लले "परमद्वैत" उपाधि धारण गरेका थिए भने जयस्थिति मल्लले "असुरनारायण" उपाधि धारण गरेका थिए। यस कालमा वैष्णव धर्मसित सम्बन्धित अनेकौं धार्मिक ग्रन्थहरू र नाटकहरूको पनि रचना भएको छन् । जस्तै “कालियमथनोपाख्यान" गोपीचन्द नाटकम्, कंशवध कृष्णचरित्र, हरिवंश, महाभारत, विष्णुधर्मशास्त्र आदि अनेको वैष्णव धर्मसँग सम्बन्धित ग्रन्थहरू संस्कृत, नेवारी र मैथिली भाषामा यसकालमा लेखिए (पृ. पू ४) ।

नेपालमा मध्यकालमा पनि वैष्णव धर्म लोकप्रिय रहेको छ। यस समयको पहिलो अभिलेख वि.स. १११३ को चाँगुनारायण मन्दिरमा रहेको चाँगु अभिलेख हो। यसका साथै मध्यकालीन अभिलेखहरूले वैष्णव धर्मको बारेमा जानकारी दिने गर्दछन् । यसकालका प्रसिद्ध राजा जयस्थिति मल्लले वैष्णव धर्मको विकासमा महत्त्वपूर्ण योगदान पुच्याएका थिए। यसका अतिरिक्त त्यसकालका कतिपय शासकहरूले वैष्णव उपाधि "परमद्वैत" धारण गरेको देखिन्छ। यसकालका शासक अरिमल्लले "परमद्वैत" उपाधि धारण गरेका थिए भने जयस्थिति मल्लले "असुरनारायण" उपाधि धारण गरेका थिए। यस कालमा वैष्णव धर्मसित सम्बन्धित अनेकौं धार्मिक ग्रन्थहरू र नाटकहरूको पनि रचना भएको छन्। जस्तै "कालियमथनोपाख्यान" गोपीचन्द नाटकम्, कंशवध कृष्णचरित्र, हरिवंश, महाभारत, विष्णुधर्मशास्त्र आदि अनेको वैष्णव धर्मसँग सम्बन्धित ग्रन्थहरू संस्कृत, नेवारी र मैथिली भाषामा यसकालमा लेखिए (पृ. पू $\gamma$ )।

नेपालमा वैष्णव धर्मसँग सम्बन्धित हालसम्म अस्तित्वमा रहेको मल्लकालीन धरोहर पाटनको कृष्ण मन्दिर रहेको छ। यो ज्यादै प्रसिद्ध र वैष्णव धर्मसँग आफ्नो अस्तित्व सन्निहित गरेर उपस्थित हालसम्म विद्यमान पूजनीय स्थल हो। शिखर शैलीमा निर्माण गरेको यो मन्दिर शैलीका दृष्टिकोणले पनि अनुपम नमूनाको रूपमा रहेको छ। यो मन्दिरको पेटीमाथिको तलामा बीचमा राधा-रूक्मिणीसहितको कृष्णको मूर्ति छ भने यसै तलामा चारैतिर विष्णुका दशावतारका मूर्तिहरू राखिएका छन् । यसप्रकार मध्यकालभरि नै वैष्णव धर्म राजाप्रजा दुवैका निमित्त एकनास रूपमा मानिने धर्मको रूपमा रहेको छ। यो युगमा वैष्णव धर्मले काठमाडौं उपत्यका तथा पूर्वी र पश्चिम नेपाल लगायत नेपालको तराईको भू-भागमा निवास गर्ने समस्त जनमानसमा ठूलो प्रभाव परेको देखिएको छ। यसै युगदेखि नै यो धर्मको विभिन्न सम्प्रदायहरूले नेपालमा पनि मान्यता पाउन पुगेको बताइन्छ (दाहाल, खतिवडा, १५९)। काठमाडौं उपत्यकामा अवस्थित प्रसिद्द कृष्णमन्दिरले नेपालीहरूमा रहेको धार्मिक आस्थालाई प्रकट गरेको छ। तत्कालीन समयमा वैष्णव धर्म जनतामा लोकप्रिय भएका कारणले त्यससमयमा शासकले जनभावनाको त्यही आस्थालाई व्यक्त गर्ने केन्द्रको रूपमा रहने गरी विशाल मन्दिरको निर्माणले शासक र जनस्तर दुवैतिर यस धर्मको उपस्थिति र अस्तित्वका बारेमा जानकारी पाउन दिएको छ। मन्दिरको आवश्यकता र औचित्य दुवै दृष्टिले तत्कालीन समाज वैष्णव धर्मानुरागी रहेको अनुमान गर्न सकिन्छ। समाजका तल्लो वर्गसम्म पनि यस धर्मको प्रभावलाई कृष्णमन्दिरले प्रतिनिधित्व र प्रतिबिम्बित गरेको छ।

वर्तमान युगमा पनि वैष्णव धर्म नेपाली जनमानसमा अत्यन्त महत्त्वपूर्ण धर्मका रूपमा विद्यमान नै रहेको छ। नेपाल र नेपालीको बीचमा विष्णु प्रिय देवताकै रूपमा रहेका छन् । यहाँका असड्ख्य मानिसहरू विष्णु भगवानप्रति श्रद्धानत छन् । केही समय अगाडिदेखि अस्तित्वमा नरहेको राजतन्त्रमा हुने राजालाई विष्णुको अवतार 
मान्ने वा विष्णुको अंश मान्ने सोच अधिकांश नेपालवासीमा रहेको थियो। नेपालको आधुनिककालमा शासन गर्ने यी शाह राजाहरूले पनि वैष्णव धर्मप्रति विशेष अनुराग राख्दै आ-आफ्नो शासनकालमा विष्णुको मूर्ति स्थापना गर्ने, पुराना मन्दिरहरूको मर्मत गर्ने गर्दथे। यस धर्मका विभिन्न शाखाहरू पनि वर्तमान नेपालमा अस्तित्वमा रहेका छन्। तसर्थ वर्तमान नेपाली समाजमा विष्णुभक्तको सड्ख्या र प्रभाव जनै धारण गर्ने ब्राम्हण, क्षेत्रीय लगायतका मानव समुदायले जप्ने गायत्री मन्त्रलाई विष्णु आराधनाकै रूपमा रहेकाले यस धर्मको वर्तमान प्रभावका बारेमा अनुमान लगाउन सकिन्छ।

\section{निष्कर्ष:}

नेपालमा वैष्णव धर्मको उपस्थिति, प्रभाव र अस्तित्वलाई पुष्टि गर्न यहाँ अवस्थित वैष्णव तीर्थस्थल, वैष्णव मन्दिर र मूर्तिहरूको अध्ययनले महत्त्वपूर्ण जानकारी उपलब्ध गराएको छ। यस ऋममा काठमाडौं उपत्यका अवस्थित चारनारायण, नेपालकै महत्त्वपूर्ण वैष्णव तीर्थस्थलहरू हुन्। चाँगुनारायण र इचंगुनारायण लिच्छवी कालदेखि नै प्रख्यात तीर्थस्थल र महत्त्वपुर्ण साँस्कृतिक सम्पदा भएका क्षेत्र हुन् भने शेषनारायण र बिशंखुनारायणका बारेमा उतिसारो जानकारी प्राप्त हुन नसकेपनि यी चारैवटा नारायणहरू एउटै राजा र शासकका पालामा निर्माण भएको अनुमान गरिएको छ(बराल, २०४४ :४४३)। उपत्यकाका अतिरिक्त नेपालका अन्य क्षेत्रहरू पनि वैष्णव धर्मवलम्बीहरूको महत्त्वपूर्ण स्थलका रूपमा वर्तमान समयसम्म पनि परिचित र प्रख्यात रहेका छन्। वर्तमान समयसम्म नेपालको सुनसरी जिल्लामा अवस्थित "बराहक्षेत्र" प्रख्यात वैष्णव तीर्थस्थलको रूपमा हालसम्म पूजनीय रूपमा अस्तित्व रहेको छ। लगभग १५ सय वर्षअगाडि निर्माण भएको मानिएको बराहक्षेत्रलाई वैष्णव धर्मका आराध्यदेव भगवान विष्णुको तेश्रो अवतारको केन्द्रको रूपमा स्वीकार गरिएको छ। नेपालकै मुस्ताङ जिल्लामा अवस्थित मुक्तिनाथ मन्दिर र त्यसको वरिपरिको क्षेत्र पनि महत्त्वपूर्ण वैष्णव तीर्थस्थलको रूपमा रहेको छ। मुक्तिनाथ क्षेत्रको भर्मण र दर्शन गर्न वर्षेनी नेपाल लगायात भारत र भुटानबाट धर्मावलम्बीहरू यहाँ आउछन्। उच्च-हिमाली क्षेत्रमा अवस्थित मुक्तिनाथको दर्शन गरे मोक्ष पाइन्छ भन्ने विश्वास रहेकाले पनि वैष्णव धर्मवलम्बीहरूको महत्त्वपूर्ण स्थलको रूपमा मुक्तिनाथ क्षेत्र रहेबाट नेपाल र नेपालीमा वैष्णव धर्मप्रति लगाव र उच्च आस्था प्रक़ट भएको छ। यसका अतिरिक्त काठमाडौं उपत्यकामा विभिन्न समयमा बनेका र हालसम्म पनि अस्तित्वमा रहेका वैष्णव धर्म अर्थात् विष्णुरूपका विभिन्न मूर्तिहरूले पनि नेपालमा वैष्णव धर्मको इतिहास र वर्तमानको सड्केत गरेको छ। नेपालमा वैष्णव धर्म स्थापित र विस्तार हुनुका मुख्य कारकका रूपमा विभिन्न कालमा बनेको कृष्णका मूर्ति र मन्दिरहरू तथा साजकीय धर्मका स्थानमा उु धर्मलाई विभिन्न कालका शासकले अड्गीकार गर्नु रहेको छ। वैष्णव धर्मको विकासको चरणमा भारतवर्षमा चार आचार्यद्वारा शंकराचार्यको “अद्वैत" दर्शनलाई परिमार्जित र संशोधित गर्ने ऋममा रामानुजद्वारा “विशिष्टोद्वैत” मध्वाचार्यद्वारा “द्वैत” बल्लभाचार्यद्वारा “ शुद्दाद्वैत" र निम्बर्कचर्या द्वारा "द्वैताद्वैत" दर्शनको विकास गरेको पाइन्छ। यसै प्रकारको विभिन्न मत र शाखाका रूपमा नेपाली समाजमा पनि वैष्णव धर्मको उपस्तिथि र अस्तित्व देखापरेको छ। यी चार मतका अतिरिक्त पछिल्लो कालमा विकसित गीता सम्प्रदाय र प्रणामी सम्प्रदायका साथै विष्णुको राम अवतारलाई मन्ने कबिर सम्प्रदायको पनि नेपालमा प्रभाव रहेको निष्कर्ष हुनआउँछ।

\section{सन्दर्भसामग्री}

अधिकारी. अनिल. (२०७४). टक्सार क्षेत्रमा प्रचलित लोकसाहित्य र संस्कृतिको अन्तर्सम्बन्ध. सहयात्रा, १(१) सहयात्रा प्रकाशन । 
काँणे. पाण्डुरंग बामन. (ई.१९९२). धर्मशास्त्रका इतिहास भाग-१. (चौ.सस्क.) हिन्दी संस्थान ।

खत्री. प्रेमकुमार. (२०४९). नेपालको सामाजिक इतिहास र धार्मिक मतहरू. एम.के. पब्लिशर्स एण्ड डिष्ट्रव्यूर्टर्स.। खत्री. प्रेमकुमार. (२०४६). नेपालको धार्मिक मत र सामाजिक संरचना. एम.के. पब्लिशर्स एण्ड डिष्ट्रिव्यूर्टर्स.। गुप्ता. राजाराम. (ई.२०१३). मनुस्मृति, सरल भाषा मे मनुस्मृति सार. पुस्तक महल । क्षेत्री. गणेश. सोमप्रसाद खतिवडा. (२०४४). हिन्दू धर्म र समाज, शिवा प्रकाशन । दहाल. पेशल. सोमप्रसाद खतिवडा (२०४६). नेपाली समाज र संस्कृतिको परिचय. एम.के. पब्लिशर्स एण्ड डिष्ट्रिव्यूर्टर ।

दाहाल. पेशल. (२०४६). नेपाली इतिहास र संस्कृति. एम.के. पब्लिसर्स एण्ड डिष्ट्रि्यूर्टर्स । नेपाल. ज्ञानमणि. (२०४०). नेपाल निरूक्त. नेपाल राजकीय प्रज्ञा प्रतिष्ठान । पाण्डेय. राजवली. (ई.१९९५ ) हिन्दू संस्कार. चौखम्बा विद्याभवन । बज्राचार्य. धनबज्र (२०३०). लिच्छविकालका अभिलेख. नेपाल तथा एशियाली अनुसन्धान केन्द्र. कीर्तिपुर । बराल. बासु. (२०४०). हिन्दू सामाजिक संगठनको प्रारूप. साका प्रकाशन । भण्डारकर. आ.जे. (ई.१९६६) वैष्णवज्म, शैवज्म र अन्य सम्प्रदायहरू. इन्डोलोजिकल बुक हाउस । भाटिया. विजय (२००६). अप्रोच टु डिस्कोर्स एनालिसिस, डिस्कोर्स स्टडिज, रोटलेज पब्लिकेसन । भाटिया. फ्लावरडयु र रोडनी. (२००६). इन्ट्रोडक्सन. डिस्कोर्स एनालिसिल फर ल्याङ्वेज टिचर्स. टायलर एन्ड फ्रान्सिस ग्रुप ।

मिश्र. जयशङ्कर. (ई.२००१) प्राचीन भारतका सामाजिक इतिहास. हिन्दीग्रन्थ अकादमी । मिश्र. रमानाथ. (ई.१९९१). प्राचीन भारतीय समाज, अर्थव्यवस्था एवं धर्म, हिन्दीग्रन्थ अकादमी। रेग्मी. जगदीशचन्द्र. (२०४०). प्राचीन नेपाली संस्कृति. साभा प्रकाशन । 